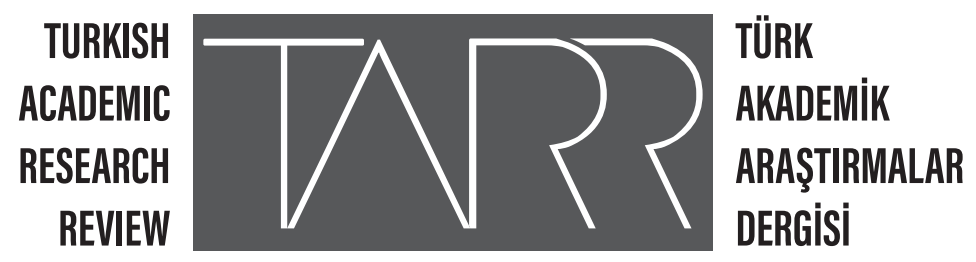

\title{
Otomotiv Sektöründe Bir Pazarlama Aracı Olarak Sosyal Medya Kullanımı: Volkswagen Örneği
}

The Use of Social Media as a Marketing Tool in Automotive Industry: Volkswagen Case

\section{Cafer Şafak EYEL, Eylem GÜLSOY, Serkan GÜN \\ Dr., Bahçeşehir Üniversitesi Sosyal Bilimler Enstitüsü Orcid 0000-0002-2391-6316}

\author{
Yüksek Lisans Öğrencisi, Bahçeşehir Üniversitesi Sosyal Bilimler Enstitüsü \\ 0000-0003-4309-7722 \\ eylemgulsoy@hotmail.com \\ Dr. Öğr. Üyesi Siirt Üniversitesi \\ Orcid 0000-0002-2501-1078 \\ Makale Bilgisi | Article Information \\ Makale Türü-Article Type | Araştırma Makalesi / Research Article \\ Geliş Tarihi-Date Received | 17 Aralık / December 2019 \\ Kabul Tarihi-Date Accepted | 25 Mart / March 2020 \\ Yayın Tarihi-Date Published | 30 Mart / March 2020 \\ Yayın Sezonu | Ocak - Şubat - Mart \\ Pub Date Season | January-February- March
}

Atıf/Cite as: Eyel, Cafer Şafak-Gülsoy, Eylem-Gün, Serkan, Otomotiv Sektöründe Bir Pazarlama Aracı Olarak Sosyal Medya Kullanımı: Volkswagen Örneği/The Use of Social Media as a Marketing Tool in Automotive Industry: Volkswagen Case. tarr: Turkish Academic Research Review, 5 (1), 1-14 doi: tarr.660013

Intihal/Plagiarism: Bu makale, en az iki hakem tarafindan incelenmiş ve intihal içermediği teyit edilmiştir. / This article has been reviewed by at least two referees and confirmed to include no plagiarism. https://dergipark.org.tr/tr/pub/tarr

Copyright (C) Published by Mehmet ŞAHIN Since 2016- Akdeniz University, Faculty of Theology, Antalya, 07058 Turkey. All rights reserved. 


\title{
Otomotiv Sektöründe Bir Pazarlama Aracı Olarak Sosyal Medya Kullanımı: Volkswagen Örneği ${ }^{1}$
}

\author{
Cafer Şafak EYEL ${ }^{2}$, Eylem GÜLSOY ${ }^{3}$, Serkan GÜN ${ }^{4}$
}

\section{Özet}

Son dönemde yaşanan teknolojik gelişim ve yenilikler bütün insanları, sosyal hayatımızı ve iş hayatımızı etkisi almış durumdadır. Alışılagelmişin dışında birçok farklılığı da beraberinde getirmiştir Bu değişikliklerden bazıları alışveriş yapmak, kendi reklam figürlerinin oluşturulması ve müşteri ile direkt olarak iletişime geçilmesidir. Bu değişikliğe sebebiyet veren en önemli faktörü dile getirmek gerekirse, internet erişim olanağının artması ve internet kullanımının yaygın bir hal alması, bunun neticesinde de sosyal medyanın ortaya çıkmasıdır. Gerek insanlar gerek de kuruluşlar ürünlerini anında sosyal mecrada tanıtabilmekte, insanlar ise bu ürünlerle ilgili düşüncelerini kolayca iletebilmekte, bu düşüncelerin üzerinde tartışabilmekte, yeni fikirler sunabilmekte ve bunlarla ilgili yorumlar alabilmektedir. Böylece gerçek dünyayı sanal ortamda yaşayabilecekleri bir yol kazanmışlardır. İçerik çözümlemesi ve literatür taraması yönteminin esas olarak belirlendiği bu çalışmada da otomotiv sektörünün içerisinde yer alan firmaların sosyal medyayı ne şekilde kullandıklarına dair cevaplar aranmıştır. Volkswagen ve Doğuş Otomotiv'in ele alındığı ve bu firmaların sosyal medyayı nasıl kullandıklarına dair analizler gerçekleştirilen bu örnekte, Volkswagen’in sosyal medyayı etkili bir biçimde kullandığ 1 bulgusu elde edilmiştir.

Anahtar Kelimeler: Sosyal Medya, Otomotiv Sektörü, VW, Doğuş Otomotiv, Pazarlama

1 Dr. Cafer Şafak EYEL danışmanlığında Eylem GÜLSOY tarafindan hazırlanıp Temmuz 2019'da sunulmuş olan “Otomotiv Sektöründe Bir Pazarlama Aracı Olarak Sosyal Medya Kullanımı: Volkswagen Örneği” isimli yüksek lisans projesinden türetilmiştir.

2 Dr., Bahçeşehir Üniversitesi Sosyal Bilimler Enstitüsü

ORCID: 0000-0002-2391-6316

safakeye1@gmail.com

3 Yüksek Lisans Öğrencisi, Bahçeşehir Üniversitesi Sosyal Bilimler Enstitüsü

ORCID: 0000-0003-4309-7722

eylemgulsoy@hotmail.com

4 Dr Öğretim Üyesi Siirt Üniversitesi

ORCID: 0000-0002-2501-1078 


\section{The Use of Social Media as a Marketing Tool in Automotive Industry: Volkswagen Case}

Recent technological developments and innovations have impact on all people, social life and business life. These developments have led to many changes in our lives. Internet shopping, creating their own advertising content, direct contact with the customer without time and place restrictions are some of these changes. The most important factor that leads to this change is the widespread use of the internet with the increase of the possibility of internet access and the social media resulting from this situation. Both individuals and corporate brands are now able to present their products instantly on social media, people can easily share their thoughts on these products, present new ideas and receive comments on them. This way, they can live the real world in a virtual environment. In this study, which is based on the literature review and content analysis method, answers were sought on how the companies in the automotive sector used social media. Social media usage of Volkswagen Turkey and Doğuş Automotive were taken for example and analyses were made on social media usage. As a result of the analyses, it was concluded that VW was used more effectively in social media.

Keywords: Social Media, Automotive Industry, Volkswagen, Doğuş Automotive, Marketing

\section{Giriș}

20. yüzyılın son zamanlarını da içine alacak bir biçimde start alan teknolojik devrimin ivmesi, geride bıraktığımız her gün oldukça hızlı bir biçimde yukarıya doğru ilerlemektedir. Teknolojik anlamda yeni her gelişme de yanında farklı birçok değişimi getirmektedir. Hem sosyal yaşamın hem de iş yaşamının birden fazla sahasında, teknolojinin sağladığı yenilikler çerçevesinde, var olan alışkanlıklar ve iş görme biçimleri değişiklik göstermektedir.

Bireysel anlam baz alındığında, bireylerin günlük yaşam hareketlerinden, boş vakitlerini değerlendirmek amacı ile yaptıkları meşgalelere kadar veya gazete ve dergi okuma davranışlarından alışveriş biçimlerine ilerleyen bir işlem bütünü, süreç gereği yeni bir inşa oluşması çerçevesinde değişik şekiller almıştır. Benzer biçimde iş yaşamının içinde de firmaların veya hizmetlerinin ya da ürünlerinin başlangıç noktasından nihai tüketiciye ulaşmasına kadar olan süreç veya firmaların kurumsal manada kendi aralarındaki iş birliktelikleri ve ilişkileri, senelerdir alışılmış şekillerden oldukça fazla değişikliklere maruz kalmıştır. Bu sebeple kurumsal manada, meydana gelen değişikliklerin şart koştuğu çalışmaları ve düzenlemeleri ortaya koyarak, yeni sistemin şart koştuğu stratejiler ekseninde hareket etme zorunluluğu, firmalar için 21. yüzyılın meydana getirdiği rekabet şartlarının mecburi kıldığı bir gerçek şeklinde göz önüne gelmektedir.

21. yüzyıla değin geçen süre zarfında firmaların hizmet veya ürünlerinin şekillendirilmesi aşamasında, bunun sonrasında tüketici kesimle buluştuktan sonra kendilerinin hem beklenti ve taleplerini hem hizmet veya ürünler ile ilgili ne düşündüklerini öğrenme durumu oldukça zayıf olmuştur. Tüketicinin aktif rol oynamadığı ve büyük oranda tek taraflı bir süreç söz konusu olmuştur. İnternetin insanların hayatında aktif olarak rol almaya başladığı 21. yüzyılın 
başlarından itibaren büyük bir aşama kaydedilmiştir. Teknolojik ilerlemeler, tüketicinin mal veya hizmetin her kademesinde dâhil olabileceği bir yapının kitlesel hizmet veya malın daha ilk aşamasından itibaren, satışın yapıldığı ve satış sonrasındaki süreçler de işin içinde olmak üzere, kendilerinin istek ve beklentilerini veya negatif ve pozitif tüm görüşlerini dile getirebilecekleri tabii bir oluşumun parçası halini almışlardır. Bu süreç de tüketiciyi geçmiş zamanlardaki gibi kendine sunulanı kabul etmek zorunda olan bir durumdan, tüm görüşlerini, fikirlerini açıkça dile getirebileceği ve aktif konumda yer alacağı bir düzenin parçası konumuna getirmiştir.

Sosyal mecra ve haberleşme tekniklerinin yani iletişim teknolojilerinin meydana getirdiği bilinmeyen sistem içinde, firmalar da özellikli olarak bilinmeyen sistemin şart koştuğu farklılıkları, bu farklılıklar ile ilgili düzenlemeleri kendi yapılarına uyarlamaya başlamışlardır. Facebook, Twitter, Instagram, Youtube gibi birden fazla sosyal paylaşım organının bir bütünü şeklinde isimlendirebileceğimiz sosyal medya olgusu da firmaların son zamanlarda bir hayli ehemmiyet gösterdikleri mecralardan bir tanesidir. İşletmelerin kendi organizasyonel yapılanmaları içerisinde yalnızca bu işle meşgul olan birimler kurmaları ve kendileri haricinde gelişim gösteren olayların kontrol edilebilmesi noktasında faal bir biçimde bir konum meydana getirme gayretleri de bu durumun en elle tutulabilir örneklerinden bir tanesidir.

İnternetin fitratı gereği üyelerinin düşüncelerini ve görüşlerini özgür bir biçimde dile getirebildiği bir platformu meydana getirmesi sonucunda, firmaların de kendi hizmet ve ürünleri ile ilgili meydana gelen pozitif/negatif düşünce birlikteliği veya fikir uyuşmazlıkları ile ilgili bilgi sahibi olmak, bu durumlara ilişkin bilinmeyen iş uygulamaları ve yollar oluşturma zorunluluğu hissetmesi, içinde bulunduğumuz iletişim ve teknoloji devrinin doğal bir sonucudur. Firmalar genel anlamı ile dijital pazarlama kapsamında gerçekleştirdikleri çalışmalar sonucunda hem müşteriler ile olan diyaloglarını güçlendirmekte ve müşterilerin düşüncelerini öğrenme avantajını elde etmektedirler hem de markalarının değerliliğini arttırma aşamasında marka imajına dair olumlu bir katkı sağlama avantajına sahip olmaktadırlar. Bu durumun yanı sıra kendi iş süreçlerini, müşteriler ile eşzamanlı olarak gerçekleşen bilgi alışverişi desteği ile yeniden yapılandırma olanağına ulaşarak, onların talep ve gereksinimlerini karşılamak ve doyuma ulaştırmak aşamasında mühim bir ayrıcalığı ellerinde tutmaktadırlar.

$\mathrm{Bu}$ çalışmada amaç; otomotiv sektöründe sosyal medyanın önemi temelinde Volkswagen firmasının sosyal medya kullanımının incelenmesi şeklinde belirlenmiştir.

\section{Sosyal Medya}

Son zamanlarda sosyal medya olarak tanımlanan internet tabanlı uygulamalarla yeni bir trend ortaya çıkmıştır. Bu internet uygulamaları, kullanıcılar ve kullanıcıların memnuniyetiyle haberdar ettikleri kişiler aracılığıyla başvuranlar arasında gittikçe daha çok artan bir etkileşim sağlamaktadır. Bu içerik, fotoğraf, video, metin ve medyaya ilişkin karışık oluşumlar içererek çeşitlilik göstermektedir. ${ }^{5}$ Sosyal paylaşım siteleri ve toplu gruplar sosyal medyada yer alan parçalardır. Bireyler firmalarının tanıtımını yapar, arkadaşlık bağlantıları kurarlar, hizmet, mal,

5 Lee Komito and Jessica Bates, "Virtually Local: Social Media and Community among Polish Nationals in Dublin", New Information Perspectives. C. 61, S. 3, 2009, s. 233. 
düşünce ve objelerin içeriğine dair sadakat gösterirler. ${ }^{6}$ Sosyal mecra büyük oranda içeriğin paylaşıldığı, aktif medyanın farklı, yeni bir türü şeklinde ayrıcalıklar sunduğu en değişik düşüncelerden bir tanesidir. ${ }^{7}$

Özellikle kitlelerin davranış biçimlerine etki etmesi açısından sosyal medya oldukça önemli bir yere sahiptir. ${ }^{8}$ Bir diğer taraftan, diğer bireylerin davranış biçimlerine etki etmede bazı ayrıcalıklara sahiptir. Üyeler için oldukça süratli elde edilen feedbackler özellikle bu duruma örnek olarak nitelendirilebilir. ${ }^{9}$ Fakat bu ayrıcalıkları anlaşılır bir biçimde göstermek kolay değildir. $\mathrm{Bu}$ yapı sosyal mecraların tesirinden ve ilerlemesinden meydana gelmektedir. ${ }^{10}$

Radyo, TV ve dergiler gibi diğer geleneksel medyalara kıyasla sosyal medyanın genel halka ulaşma eğilimi daha yüksektir. Buna ek olarak, internet kullanıcıları bilgi arama amaçlı sosyal medyaya doğru ilerlemektedir. ${ }^{11}$

Kullanıcıların sosyal medyayı tercih sebepleri amaca göre değişiklik göstermektedir. Bireylerin bekledikleri her zaman farklılık taşır. Bu bağlamda değişik kullanımlar ve hazlara da neden olabilmektedir. Kişiler kimi zaman bilgi edinme, araştırma, iş, ticaret kimi zaman da arkadaşlık kurma ve eğlence amacı ile sosyal medyayı kullanmaktadır. Birey o an içinde yer aldığı durum ve gereksinime göre sosyal medyayı kullanmaktadır. Bu çalışma kapsamında Facebook, Instagram ve YouTube incelemeye alınmıştır.

Facebook sosyal ağlar içinde en çok kullanılan sitedir. Bireyler yeni ilişkiler kurmak veya hali hazırdaki ilişkilerinin gücünü arttırmak, vakit geçirmek, kendilerini anlatabilmek veya eğitim için Facebook'u değerlendirebilmektedirler. Facebook vasıtasıyla bireyler saygınlık kazanabilmekte insanlarla temasta bulunabilmekte, yerlerini belirtmekte ve fotoğraf, video, görüş vb. paylaşabilmektedir. ${ }^{12}$

Instagram 2010 yılında kurulmuştur. Instagram kullanıcıların fotoğraflarını bazı dijital filtrelerle paylaşabilme özelliği olan bir sosyal ağ sitesidir. Ayrıca kullanıcılar bunları Twitter ve Facebook da dâhil olmak üzere, diğer sosyal ağ hizmetleri ile bağlayabilmekte ve paylaşabilmektedir. Instagram kullanıcıları fotoğrafları alıp yükleyebilir, Instagram'ını diğer sosyal ağ siteleri ile bağlayabilir ve bu özelliklerin yanı sıra diğer kullanıcıların paylaşılan fotoğraflarını görmek için onları takip edebilir. Ayrıca Instagram, son zamanlarda kullanıcıların fotoğrafla

6 Brian Solis, Sosyal Medya İçin Temel Rehber, 2010, erişim tarihi 09.05.2019, s. 6, http://www.onecaribbean.org/content/ files/essentialGuidetoSocialMedia.pdf

7 Antony Mayfield, What is Social Media, icrossing, E-Book, 2010, erişim tarihi 04.05.2019, s. 6, http://www.icrossing. co.uk/fileadmin/uploads/eBooks/What_is_Social_Media_iCrossing_ebook.pdf

8 Alan Kirschenbaum, "Generic Sources of Disaster Communities: A Social Network Approach", International Journal of Sociology and Social Policy. C. 24, S. 10/11, 2004, s. 99.

9 Eric Gilbert, and Karrie Karahalios, "Predicting Tie Strength with Social Media”, CHI 2009. April 4-9, 2009 , s. 2

10 Kirschenbaum, s. 102

11 W. Glynn Mangold and David J. Faulds, "Social Media: The New Hybrid Element of The Promotion Mix", Business Horizons. C. 52, S. 4, 2009,, s. 361; Schivinski, Bruno and Dariusz Dabrowski, "The Impact of Brand Communication on Brand Equity Dimensions and Brand Purchase Intention through Facebook", Gdansk University of Technology, Faculty of Management and Economics. C. 4, S. 4, 2013, s. 20.

12 Ayça Çekiç Akyol, Mevlüt Akyol ve Alper Yılmaz, "Yeni Medya Araçlarında Görsel İletişim: Otomobil Markalarının Sosyal Medya Kullanımları Üzerine Bir İnceleme”, Selçuk İletişim. C. 8, S. 2, 2014, s. 5-6. 
konumlarını paylaşabilecekleri ve kişisel bilgileri hesaplarına ekleyebileceği gibi yeni özellikleri eklemiştir. ${ }^{13}$

YouTube, bir video paylaşım sitesidir. "Broadcast Yourself; Kendini Yayınla" sloganı ile yola çıkmıştır. 2005 yılında üç PayPal çalışanı tarafından kurulmuş, 2006 yılında Google tarafından satın alınmıştır. Youtube dünyada en fazla kullanılan video paylaşım sitesidir. Youtube'a her 1 dakikalık dilimde 60 saate varan görüntü içeriği yüklenmektedir. Her gün 4 milyardan fazla görüntü oynatılmaktadır. 39 ülkede ve 54 dilde yerelleşmiş olan Youtube’u her ay 800 milyondan fazla kullanıcı ziyaret etmektedir.

\section{Sosyal Medya Pazarlaması}

Şirketler ve müşterileri arasındaki kusursuz iletişim biçimlerinden bir tanesi sosyal medya pazarlamasıdır. Kurumlar tüketiciler ile kabul edilebilir ve anlayışlı bir biçimde iletişim kurmak amacı ile sosyal medyayı kullanabilir. ${ }^{14}$ Hem teknolojinin hem de internetin oldukça hızlı bir biçimde ilerlemesi ile beraber gerek kullanıcı profili gerekse pazarlama yöntemlerinde farklılığa gidilmiş, bu sayede kullanıcılarım tutumlarıyla düşüncelerine uyum sağlayan farklı pazarlama anlayışları gün yüzüne çıkmıştır. Sosyal medya pazarlaması, yeni pazarlama anlayışında kendine bir yer bulmuştur. Bireylerin günlük diyalog biçimlerini ve alanlarını farklılaştırmakla yetinmemiş, bunun yanı sıra üyelerin ve firmaların ürün veya hizmetlerine karşı tutumlarını ve satın alırken dikkat ettikleri hususları da farklılaştırarak, kullanıcıların pazarlamanın her etabında etkili görev almasına imkân sağlamıştır. Bunun sonucunda da, bir alışveriş merkezine uğray1p gereksinimlerini gidermek veya satı̧s sorumlusunun ikna yeteneğinden etkilenerek hizmet veya ürünü kullanan bireylerin memnuniyetsizliği ya da beğenisini ilettiği değerlendirmelerini bilmeden veya hizmeti bitirerek hali hazırda yer alan satın alım alışkanlıklarını farklılaştırmış, bundan sonra sosyal medya aracılığı ile bir alı̧̧veriş merkezine veya dükkâna gitmeden dijital alanda satın alma işlemini gerçekleştirebilmekte, almayı düşündüğü ürün ile alakalı kullanıc1ların deneyimlerini, incelemelerini görerek satın almak adına karar vermekte, bunun yanı sıra kullanmaktan beğeni duyduğu veya memnuniyetsizliğini belirttiği ürün hakkında görüş belirterek bunu sosyal medyada yayınlayabilmektedir. ${ }^{15}$

Firmalar kullanıcılarının bir ürünü satın alırken verdikleri kararların öncesinde sosyal medya yardımıyla ürünler ile ilgili bilgi seviyesinin yükselmesinden ötürü kullanıcıların talep ve beklentilerine uygun biçimde pazarlama yöntemleri araştırmaktadır. ${ }^{16}$ Bundan dolayı sosyal medya; düşünceler, satın almaya yönelme, bilgi edinme, satın aldıktan sonra ölçümleme vs. tüketici davranışlarının birden farklı tarafina tesir eden mühim bir durumdur. Böylelikle şirketler, sosyal medyaya ait bu gücün işletmenin yararına hangi biçimde değerlendirilebileceğini incelemektedir. Firmalar kullanıcıdan kullanıcıya mesajları direkt olarak denetleyemezken, bu

13 Sook Huey Lim, "How Instagram Can Be Used as A Tool in Social Network Marketing”, Doctoral Dissertation, Center for Southern New Hampshire University (SNHU) Programs HELP College of Art and Technology, 2014.

14 Mangold and Faulds, s. 361.

15 Tugay Arat ve Gonca Dursun, "Seyahat ve Konaklama Tercihi Açısından Sosyal Paylaşım Sitelerinin Kullanımı”, Selçuk Üniversitesi Sosyal Bilimler Meslek Yüksekokulu Dergisi. C. 19, S. 41, 2016, s. 113.

16 Lütfiye Can ve Ayhan Serhateri, “Sosyal Medya Reklamlarının Markaya Yönelik Tutuma Etkisi: Facebook Üzerinde Bir Uygulama”, Balkan ve Yakın Doğu Sosyal Bilimler Dergisi. C. 2, S. 3, 2016, s. 16-17. 
denetimi kullanıcıların başka kullanıcılar ile olan söylemlerine tesir ederek gerçekleştirebilirler. ${ }^{17} \mathrm{Bu}$ bakımdan sosyal medya ile yapılan pazarlama; kullanıcılar ile firma arasında diyaloğun gerçekleştirilmesini ve de sürdürülebilir olmasına olanak veren çok geniş çaplı topluluklara pazarlama çalışmalarının ulaştırılmasına imkân veren; kullanıcının talep, beklenti ve eleştirilerinin öğrenilmesine olanak sağlayan sosyal medyayı kullanan üyelerini ve gereçlerini firmanın pazarlama alanındaki amaçları doğrultusunda değerlendirmesine yarayan bir yoldur. ${ }^{18}$

Kullanıcılar bir malı veya hizmeti satın almadan önce sosyal çevresinin o malla/hizmetle ilgili tecrübelerini, beğenilerini veya memnuniyetsizliklerini öğrenmek için gayret etmekte ve de satın alırken verdikleri kararlarını bu değerlendirmeler ışı̆̆ında biçimlendirmektedirler. Benzer vaziyet sosyal medya alanında da mevcuttur. Bu bağlamda günümüzde kullanıcılar, sosyal mecralarda bir malı satın alırken verdikleri kararlarını firmaların pazarlama yöntemlerinden taraf olmayan ve güvenli bulduğu üye görüşlerini irdeleyerek almaktadır. ${ }^{19}$

Firmalar sosyal medya profillerinde reklamcılık ve pazarlama çalışmalarını mal veya hizmetleri ile alakalı görsel, kampanya ve indirim şeklinde gönderiler paylaşarak sağlayabilir. Bunun yanı sıra kişisel özel ileti paylaşımı, kullanıcı görüşlerine, memnuniyetsizliklerine ve problemlerine dönüş sağlayarak gerek var olabilecek gerekse hali hazırdaki kullanıcı kitlesine etki ederek firma ile kullanıcıları arasındaki iletişimi kuvvetlendirebilir. ${ }^{20}$ Sosyal medya, üyelerinin firmalar için yazdığı tweetler, yaptıkları görsel ve video paylaşımlarla kartopu etkisi yaratarak firmanın saygınlığına, marka imajına, gelir ve giderlerine, bunun yanı sıra firmanın yaşamını sürdürebilir kılmasına tesir edebilir. Bu sebeple firmaların, sosyal medyanın anlamını, nasıl yürütüldüğünü, en önemlisi de kullanıcı ile ne şekilde diyaloğa geçebileceğini anlaması gereklidir. ${ }^{21}$

\section{Otomotiv Sektörü}

Globalleşen iş hayatında daimi ve süratli bir değişiklik içinde olan otomotiv sektörü, son zamanlarda bir hayli önemli bir düzeye ulaşmıştır. Otomotiv sektörü dünyamız ekonomisinin hemen hemen \%5'lik bölümünü oluşturmaktadır ve demir-çelik, petro-kimya, plastik, savunma, altyapı, tedarikçi vb. alanlarla direkt ya da endirekt olarak ilişkilidir. ${ }^{22}$ Pazarın genişliği ve artan değerinin neticesinde gerçekleşen yoğun rekabet ortamında, ${ }^{23}$ otomotiv sektörü temel ve

17 Mangold and Faulds, s. 358-359.

18 Can Yılmazdoğan ve Çağıl Özel, "Sosyal Medya Pazarlamasının Otellerdeki Kullanımının Yararlarına Yönelik Yönetici Algılarının Belirlenmesi: Antalya Örneği”, Dokuz Eylül Üniversitesi İ̧sletme Fakültesi Dergisi. C. 15, S. 1, 2014 , s. 40.

19 Erkan Akar, "Sanal Toplulukların Bir Türü Olarak Sosyal Ağ Siteleri - Bir Pazarlama İletişimi Kanalı Olarak İşleyişi”, Anadolu Üniversitesi Sosyal Bilimler Dergisi. C. 10, S. 1, 2010, s. 115.

20 Murat Toksarı, Mehmet Mürütsoy ve Muhammet Bayraktar, "Tüketici Algılarını Etkileyen Faktörlerde Sosyal Medyanın Rolü: Niğde Üniversitesi İİBF Örneği”, Uşak Üniversitesi Sosyal Bilimler Dergisi. C. 7, S. 4, 2014, s. 7.

21 Jan H. Kietzmann v.diğ., "Social Media? Get Serious! Understanding The Functional Building Blocks of Social Media”, Business Horizons. C. 54, S. 3, 2011, s. 241-242.

22 Sercan Pişkin, Otomotiv Sektör Raporu: Türkiye Otomotiv Sanayii Rekabet Gücü ve Talep Dinamikleri Perspektifinde 2020 $\dot{I}_{\zeta ̧}$ Pazar Beklentileri, 2017, erişim tarihi 12.05.2019, s. 12, https://www.taysad.org.tr/uploads/dosyalar/06-02-201709-59-170206-Otomotiv_Sektor_Raporu_TSKB-2208.pdf

23 Marcello Chiaberge, "New Trends and Developments in Automotive Industry", in Automobile Engineering, 2011, erişim tarihi 05.05.2019, s. 390, https://www.intechopen.com/books/new-trends-and-developments-in-automotive-industry 
yan sanayiyle özellikli olarak ekonomik bakımdan ilerlemiş ve ilerlemekte olan şehir ve ülkeler açısından oldukça önemli bir yere sahiptir. ${ }^{24}$

Otomotiv sektöründeki ilerlemelerle alakalı olarak alanyazında muhtelif düşünceler vardır. En başta araçlarla ilişkilendirilen sektörde, sırasıyla elektriğin ve buharın gücüne dayandırılmı̧̧ vasıtalar ilerletilmiş, çağımızda kullanımı sağlanan yanmalı motorlu aracın yapımı da 1886 senesinde Karl Benz, Gottlieh Daimlerce ortaya konmuştur. ${ }^{25} 1900$ 'lü senelerden itibaren ilk araç yapımından sonra Henry Ford'a ait olan seri imalat yaklaşımıyla birlikte "T" prototipinin yapımına start verilmesi sektördeki başlangıç evreleri şeklinde tanımlanmaktadır. ${ }^{26}$

Uluslararası Motorlu Araç Üreticileri Derneği’nin yayımladığı rakamlar ele alındığında, 2016 senesinde 2015 'e kıyasla global üretim \%5 şeklinde bir artı̧̧ göstermiştir. Üretimin yarısından çoğu Asya ve Okyanusya'da meydana gelmiştir. ${ }^{27}$ Avrupa ve ABD'deki sektör üstünlüğü geçtiğimiz on senede yerini Asya ve Okyanusya ülkelerine devretmiştir. ${ }^{28}$ Bununla birlikte Hindistan, Meksika, Çin, Türkiye gibi doymamış iç pazara sahip gelişmekte olan ülkelerdeki taleplerin pazar ve üretim dinamikleri açısından itici güç olduğu görülmektedir. ${ }^{29}$ Günümüzde sektör, üretim ve satış değerleri açısından analiz edildiğinde Çin’in açık bir şekilde önde olduğu görülmektedir. ${ }^{30}$

Türkiye'de oldukça hızlı bir şekilde gelişim gösteren sektörlerden bir tanesinin de otomotiv

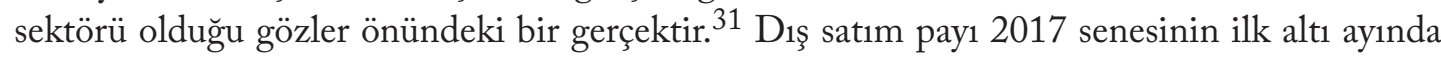
\%8,2'lik bir oranda yükseliş kaydetmiştir. Başka sektörlere nazaran en çok dış satımın yapıldığı alanın otomotiv olduğu görülmüştür. ${ }^{32}$

\section{Otomotiv Sektöründe Sosyal Medya Uygulamaları: Volkswagen Örneği}

\subsection{Yöntem}

Çă̆ımızda diğer sektörlerde yarışan firmalar gibi otomotiv sektöründe boy gösteren şirketlerin pek çoğu sosyal medyadan yararlanmanın kendilerine sağlayacă̆ı avantajları görerek, bu konuya uyum sağlamaya çaba göstermektedirler. Fakat bu gayretlerinin ne kadarlık bir kısmının amacına ulaştığının ve hedef müşteri kitleleri tarafından bu çabaların görünürlügünün

24 William J. Mitchell, Chris E. Borroni-Bird and Lawrence D. Burns, Reinventing The Automobile Personal Urban Mobility for The 21st Century, U.S.A.: The MIT Press, 2010, s. 1; Recep Çiçek ve Seda Çağma, "Türk Otomotiv Ana Sanayinin Uluslararası Pazardaki Rekabet Gücü: Otomotiv Yan Sanayi Üzerine Bir Uygulama”, Selçuk Üniversitesi İktisadi ve İdari Bilimler Fakültesi Sosyal ve Ekonomik Araştırmalar Dergisi. S. 28, 2014, s. 260.

25 Mitchell v.diğ., s. 10-11.

26 Çağatay Tunçsiper, "Otomotiv sektörünün makro analizi ve strateji yönetimi”, Yüksek Lisans Tezi, Balıkesir Üniversitesi Sosyal Bilimler Enstitüsü, 2014, s. 2.

27 OSD, Otomotiv Sanayii 2016 Yılı Küresel Değerlendirme Raporu, 2017, erişim tarihi 15.05.2019, s. 7, http://www.osd. org.tr/sites717upload/files/2016_Degerlendirme_Raporu-2250.pdf

28 Erkan Y1lmaz, “Türkiye Otomotiv Sanayinin Gelişimi ve İkinci El Otomobil Talep Fiyatının Belirleyicileri”, Yüksek Lisans Tezi, Gaziosmanpaşa Üniversitesi Sosyal Bilimler Enstitüsü, 2016, s. 36.

29 Pişkin, s. 19-20

30 Yilmaz, s. 38

31 Karbuz, Fahri, And Silahçı ve Emrah Çalı̧kan, Otomotiv Sektör Raporu, İstanbul: İstanbul Ticaret Odası Ekonomik ve Sosyal Araştırmalar Şubesi, 2017, s. 54.

32 OSD, s. 8 
bilinmesi, araştırılması gerekli olan bir durumdur. Bu çalışmada, Volkswagen AG özelinde, otomotiv piyasasında sosyal medya kullanımının ve sosyal medyadaki çalışmaların pazarlama faaliyetlerine olan etkisinin ortaya konması amaçlanmıştır. Bu doğrultuda, orta düzeyde üretim gerçekleştiren ve ikinci kademedeki tüketici kitlesini hedefleyen Volkswagen firmasının Facebook, YouTube ve Instagram profilleri; diyaloğun görsel/anlaş1lır konusunun nesnel, sistemli ve rakamsal tanımlamalarını gerçekleştiren araştırma ve geliştirme yolu ${ }^{33}$ olan içerik analizi vasıtasıyla incelenmiştir. Araştırma, 1 Haziran 2019 - 30 Haziran 2019 tarihleri arasında gerçekleştirilmiştir.

\subsection{Volkswagen AG}

Volkswagen AG Almanya'da 1937 y1lında tek model halk tipi otomobil üretimi için Nasyonal Sosyalist Alman İşçi Partisi tarafindan Alman Otomotiv Birliği’ne kurdurulan bir otomobil firmasıdır. Türkiye'ye ise 1994 senesinde Doğuş Otomotiv distribütörlüğü ile giriş yapma imkânı bulmuştur. Doğuş Otomotiv günümüzde Volkswagen, Audi, Seat, Skoda, Porsche, Bently gibi otomotiv markalarının Türkiye genel distribütörüdür. Doğuş Otomotiv’in iki binden fazla çalışanı vardır. Türkiye piyasasının önemli firmalarından bir tanesidir. Volkswagen Türkiye çapında 36 ilde 71 yetkili satıcı ve 78 yetkili servisi ile müşterilerine hizmet vermeye devam etmektedir. ${ }^{34}$

\subsection{Volkswagen Firmasının Web Sitesi}

Halkla ilişkiler amacıyla meydana getirilen web sitelerinde, ziyaretçilerin sitede yeteri kadar kalması, keyifli zaman geçirmesi, gerekli durumlarda kurumla etkileşimde bulunması, ilgililik seviyesini yükseltmesi ve sürdürülebilirliğin sağlanması hedeflenmektedir. Bu hedefler çerçevesinde Volkswagen'in kurumsal web sitesinde ürünlerinin lansmanı gerçekleştirilmekte, reklam amaçlı videoları gösterime sunulmakta, satış yapıldıktan sonra verilen hizmetlerle alakalı bilgiler verilmekte, kampanyalar ve araç fiyatlarıyla ilintili hususlarda anlaşılır bilgiler yayınlanmaktadır. Volkswagen’in "http://binekarac.vw.com.tr" linkine sahip sitesinden; kurumsal kimlik ögelerinden firmanın amblemi ve iletişim bilgilerine, kurumun meydana getirmiş olduğu ürün çeşitliliği, firmanın tarihi gibi birden fazla özelliğe ulaş1labilmektedir. Volkswagen sosyal medya platformlarından Facebook, Twitter, YouTube ve Instagram'1 kullanmaktadır. Ancak firmanın web sitesinde de, bu sosyal medya profilleriyle ilgili bilgilere yer ayrılmış durumdadır.

\subsection{Volkswagen Firmasının Facebook Sayfası}

Volkswagen 14 Ağustos 2010 tarihinde Facebook’a katılım göstererek otomotiv piyasasında sosyal medyadan yararlanan ilk firmalardan biri olmuştur. Facebook’tan yararlanmaya başladığ 1 günden itibaren firmanın Facebook’taki takipçi rakamlarına göz gezdirildiğinde; 33.854 .191 kişi tarafından takip edildiği, 33.905.686 kişininse Volkswagen’in resmi Facebook sayfasını beğendiği ve onunla alakalı konuştuğu, 52.638 üyenin de sayfaya ziyaret gerçekleştirdiğ göz

33 Orhan Gökçe, İçerik Çözümlemesi-Sosyal Bilimlerde Bir Araştırma Yöntemi, Konya: Selçuk Üniversitesi İletişim Fakültesi Yayınları, 1995, s. 16.

34 Doğuş Otomotiv Resmi Web Sitesi, erişim tarihi 10.05.2019, www.dogusotomotiv.com.tr 
önüne serilmektedir. Yine Volkswagen'in resmi Facebook hesabının bir aydaki ortalama beğeni sayısı 22.000, yorum sayısı ise 1.000'dir. Elde edilen bu sonuçlar değerlendirildiğinde, Volkswagen'in Facebook'u aktif bir biçimde kullandığı ve hedef müşteri kitlesine ulaşmak amacıyla kullandığ 1 görülmektedir.

Tablo 1. Volkswagen Türkiye Facebook sayfası verileri

\begin{tabular}{|c|c|c|c|}
\hline \multirow{2}{*}{ Volkswagen } & Beğeni & Hakkında Konuşan Sayısı & Ziyaret Eden Sayısı \\
\cline { 2 - 4 } & 33.905 .686 & 33.854 .191 & 52.638 \\
\hline
\end{tabular}

Volkswagen, Facebook resmi sayfasında reklamlara, etkinliklere, takipçilerinin yaptığı yorumlara, araç tanıtımlarına kampanyalara ve paylaşımlara yer ayırmaktadır. Bayramlarda, özel günlerde (anneler günü, babalar günü gibi), hafta sonlarında her kesimden potansiyel müşterilere ulaşabilmek maksadıyla gönderiler yayınlamaktadır. Örneğin; "Bugün Günlerden Volkswagen” kampanyasıyla Facebook’ta büyük bir hedef kitlesinin dikkatini üzerinde toplamış, sınırlı sayıda aracı bu kampanya kapsamında satışa sunarak, sosyal medyanın araç satışı üzerindeki etkisini göz önüne sermiştir. Bunun yanı sıra "Volkswagen Hurda Kampanyası" ile yine Facebook’ta takipçilerine seslenerek, kampanyanın geniş bir kitleye ulaşmasını hedeflemiştir. Bu kampanyanın Facebook'ta yayınlanmasının ardından çağrı merkezine gelen arama sayısı, bir gün içerisinde iki katı kadar artmış, insanlar kampanya detayları ile ilintili bilgi sahibi olmak üzere pek çok arama gerçekleştirmiştir. Volkswagen’in belirli tarihlerde gerçekleştirmiş olduğu ve katılım oranının yüksek olduğu bazı Facebook etkinlikleri ise şunlardır:

i. "White Night” Fashion's Night Out'ta seni bekliyor!

ii. $4 \mathrm{MOTION}{ }^{\circledR}$ Experience - Kartalkaya

iii. Volkswagenler İstanbul Park"ta!

iv. Volkswagen Junior Masters Futbol Turnuvası

Yukarıda belirtilen etkinlikler Volkswagen’in çok daha geniş kitlelere ulaşabilmesine vesile olmuştur. Bu etkinlikler sonucunda kullanıcıların ilgili etkinlik tarihlerinde Facebook sayfasında marka ile ilgili yaptıkları yorumlar artmış, kullanıcılar araçlara ilişkin olumlu ve/veya olumsuz düşüncelerini yine etkinlik kapsamında dile getirmişlerdir.

\subsection{Volkswagen Firmasının YouTube Sayfası}

Volksagen 28 Şubat 2011 tarihinde katıldı̆̆ı YouTube'da 34.917 aboneye kadar ulaşmıştır. Firmanın kendi web sayfasında, YouTube üzerinden yayınlamı̧ olduğu görüntülerle reklamlar 47.468.479 defa görüntülenmiştir. Volkswagen’in Türkiye YouTube sayfasında yayınlanan ilk videosu, 27 Şubat 2012 tarihindeki "Kı̧̧ Sürüş Kılavuzu” reklamıdır ve bu reklam üyeler tarafindan 26.334 defa görüntülenmiştir. 13 Mayıs 2019 tarihinde en son yayınlanan videosuna bakıldığında ise, 89.337 görüntülenmeye rastlanmıştır. Bu durum göstermektedir ki, sosyal medya kullanımının her geçen gün artması, markaların bilinirliğini arttırmakta, markalara olumlu ve olumsuz geri dönüşler yapılmasını kolaylaştırmaktadır. Üyeler, YouTube sayfasından dahi kolayca deneyimlerini paylaşarak, diğger kullanıcılara bir anlamda yol gösterici olmaktadır. 


\subsubsection{Volkswagen Firmasının Instagram Sayfası}

Volkswagen'in “vwturkiye” şeklinde bir Instagram profili bulunmaktadır. Volkswagen'in Instagram üzerinde 375 bin takipçisi vardır. Volkswagen tarafindan Haziran 2019 sonuna değin 1951 gönderi yapılmış olup, markanın takip ettiği kullanıcı sayısı ise 18'dir. Volkswagen Instagram sayfasının bir ayda aldığı beğeni sayısı 120.000 ve yorum sayısı ise 2.000 kadardır.

Tablo 2. Volkswagen Türkiye Instagram sayfası verileri

\begin{tabular}{|c|c|c|c|}
\hline \multirow{2}{*}{ Volkswagen } & Paylaşılan Fotoğraf & Beğeni & Yorum \\
\cline { 2 - 4 } & 1.951 & 1.958 .256 & 30.000 \\
\hline
\end{tabular}

\section{Sonuç}

Çağımız insanının vazgeçilmezi halini alan internet erişimi; toplumsal değerlerin, beklentilerin ve davranış biçimlerinin esaslı bir değişime uğramasına sebep olmuştur. Bu büyük değişikliğin farkını anlayan firmalar hedef kitlelerine ulaşmak ve onlarla karşılıklı diyaloğu sağlamak için alışılagelmiş halkla ilişkiler aktivitelerinin dışında, internetin kendilerine sağladığ sınırsız olanaklardan yararlanmaya başlamışlardır. Bu olanaklardan bir tanesi de sosyal medyadır. Sosyal medya ile firmalar pazarlama aktivitelerinin tanıtımını gerçekleştirip duyurabilmekte, hedef kitleleriyle diyalog haline geçebilmektedirler.

Otomotiv firmaları da gizli ve potansiyel müşterilerine erişim sağlamak, firma tanınırlı̆̆ını üst seviyeye çıkarmak, pozitif bir imaj çizmek ve hedef kitlelerle diyalog kurmak için Facebook, Twitter, YouTube, Instagram gibi sosyal medya mecralarında birden fazla değişik çalışma ortaya koymaktadırlar. Gayesi sosyal medya pazarlaması olan bu faaliyetlerin hangi seviyede olduğu, hedef müşteri kitlesine ulaşılıp ulaşılmadığı ve en çok tercih edilen sosyal medya ağlarının hangileri olduğunu ortaya koymak üzere, bu çalışma kapsamında Volkswagen firmasının sosyal medya hesaplardan Facebook, YouTube ve Instagram profilleri incelenmiştir.

Otomotiv sektöründe etkinlik gösteren firmalar pazarlama amaçlı çalışmaları için uzun yıllardan beri sosyal medyayı yoğun şekilde kullanmaktadırlar. Volkswagen; sosyal medyada kurumsal değerlere, sosyal sorumluluklara, sponsorluklara, çevre ile ilgili raporlara, şirketin kuruluşu hakkındaki haberlere, yeniliklere, kullanılan teknolojilere, otomobil modellerini tanıtan bilgilere, satış sonrası hizmetlere, finansal hizmetlere, iç hedef kitlelere yönelik ücretlendirmelere, kurum içi iletişim faaliyetlerine ve sosyal hayat ile ilintili verilere yer vermektedir. İç ve diş hedef müşteri kitlelerine ulaşmada pazarlama aracı olarak sosyal medya ağlarından Facebook, Instagram ve YouTube kullanılırken; bu ağlardan en fazla ise Facebook tercih edilmektedir.

Kampanyalardan oyunlara, etkinliklere, üyelerin yaptıkları yorum ve paylaşımlara, pazarlama aktivitelerinden bayram kutlamalarına, web sayfasına katılımı arttırmak ve iletişimi sürdürmeye yönelik soru etkinliklerine değin birçok aktiviteye Facebook sayfalarında alan ayırmaktadır. Volkswagen Facebook’ta yaptıkları paylaşımlara yüksek ölçüde geri bildirim (feedback) almaktadır. Oldukça büyük bir kısmı olumlu olan geri bildirimlerin sosyal medya pazarlamasında 
lazım olan "karşıllklı iletişim”, "hedef müşteri kitlesine erişim” ve "hedef müşteri kitlelerin gözünde pozitif imaj oluşturma” istekleri de Facebook ile gerçekleşmektedir.

Volkswagen, Facebook'tan biraz daha az olmak üzere Instagram'dan başarılı biçimde yararlanmaktadır. Instagram'da pazarlama maksatlı iletilerine büyük ölçüde beğeni ve yorum almaktadır. Hedef müşteri kitlelerin dikkatini üzerinde toplamak, sayfayı ziyaret etmelerini sağlamak amacı ile de Instagram'da yarışma aktivitelerine alan ayırmaktadır.

Volkswagen, sosyal medya pazarlaması doğrultusunda YouTube'u başarılı bir biçimde kullanmakta, buradan firmaya ait ya da firmanın mühim olarak gördüğ ü görüntüleri ve videoları hedef müşteri kitlesine ulaştırmakta, böylelikle üyeleri bilgilendirmeye çalışmaktadır.

Sonuç olarak, otomotiv sektöründe yer alan Volkswagen firması, modern sosyal medya pazarlama araçlarından Facebook, Instagram ve YouTube'dan aktif ve yoğun bir biçimde yararlanmaktadır. En fazla ise Facebook'u kullanmaktadır. Geleneksel medyanın yerine geçen bu sosyal medya araçları ile hedef müşteri kitleleriyle diyalog haline geçip, firmayı tanınır hale getirip, sektör içerisinde farklılaşma yoluna gitmeye, yarışabilmeye ve kurumsal imaj meydana getirmeye çabalamaktadır.

$\mathrm{Bu}$ tip çalışmaların daha detaylı ve kapsamlı bilgiler içermesi bakımından, alanda çalışma gerçekleştirecek olan diğer araştırmacılara, incelenen sürenin daha uzun olması ve örneklem sayısının fazlalaştırılması önerisinde bulunulmaktadır. Ayrıca belli bir firmanın farklı ülkelerdeki temsilciliklerinin sosyal medya hesaplarının karşılaştırılması da önerilebilir.

\section{Kaynakça}

Akar, Erkan, "Sanal Toplulukların Bir Türü Olarak Sosyal Ağ Siteleri - Bir Pazarlama İletişimi Kanalı Olarak İşleyişi”, Anadolu Üniversitesi Sosyal Bilimler Dergisi. C. 10, S. 1, 2010, s. 107-122.

Arat, Tugay ve Gonca Dursun, "Seyahat ve Konaklama Tercihi Açısından Sosyal Paylaşım Sitelerinin Kullanımı”, Selçuk Üniversitesi Sosyal Bilimler Meslek Yüksekokulu Dergisi. C. 19, S. 41, 2016, s. 111-128.

Can, Lütfiye ve Ayhan Serhateri, "Sosyal Medya Reklamlarının Markaya Yönelik Tutuma Etkisi: Facebook Üzerinde Bir Uygulama”, Balkan ve Yakın Doğu Sosyal Bilimler Dergisi. C. 2, S. 3, 2016, s. $16-28$.

Chiaberge, Marcello, "New Trends and Developments in Automotive Industry", in Automobile Engineering, 2011, erişim tarihi 05.05.2019, https://www.intechopen.com/books/new-trendsand-developments-in-automotive-industry

Çekiç Akyol, Ayça, Mevlüt Akyol ve Alper Yılmaz, "Yeni Medya Araçlarında Görsel İletişim: Otomobil Markalarının Sosyal Medya Kullanımları Üzerine Bir İnceleme”, Selçuk İletişsim. C. 8, S. 2, 2014, s. $119-131$

Çiçek, Recep ve Seda Çağma, “Türk Otomotiv Ana Sanayinin Uluslararası Pazardaki Rekabet Gücü: Otomotiv Yan Sanayi Üzerine Bir Uygulama”, Selçuk Üniversitesi İktisadi ve İdari Bilimler Fakültesi Sosyal ve Ekonomik Araştırmalar Dergisi. S. 28, 2014, s. 260-277.

Doğuş Otomotiv Resmi Web Sitesi, erişim tarihi 10.05.2019, www.dogusotomotiv.com.tr

Gilbert, Eric and Karrie Karahalios, "Predicting tie strength with social media", CHI 2009. April 4-9, 2009. 
Gökçe, Orhan, İçerik Çözümlemesi-Sosyal Bilimlerde Bir Araştırma Yöntemi, Konya: Selçuk Üniversitesi İletişim Fakültesi Yayınları, 1995.

Karbuz, Fahri, And Silahçı ve Emrah Çalışkan, Otomotiv Sektör Raporu, İstanbul: İstanbul Ticaret Odası Ekonomik ve Sosyal Araştırmalar Şubesi, 2017.

Kietzmann, Jan H. v.diğ., "Social Media? Get Serious! Understanding The Functional Building Blocks of Social Media”, Business Horizons. C. 54, S. 3, 2011, s. 241-251.

Kirschenbaum, Alan, “Generic sources of disaster communities: A social network approach”, International Journal of Sociology and Social Policy. C. 24, S. 10/11, 2004.

Komito, Lee and Jessica Bates, "Virtually Local: Social Media and Community among Polish Nationals in Dublin", New Information Perspectives. C. 61, S. 3, 2009.

Lim, Sook Huey, "How Instagram Can Be Used as A Tool in Social Network Marketing”, Doctoral Dissertation, Center for Southern New Hampshire University (SNHU) Programs HELP College of Art and Technology, 2014.

Mangold, W. Glynn and David J. Faulds, "Social Media: The New Hybrid Element of The Promotion Mix", Business Horizons. C. 52, S. 4, 2009, s. 357-365.

Mayfield, Antony, What is social media, icrossing, e-book, 2010, erişim tarihi 04.05.2019, http://www. icrossing.co.uk/fileadmin/uploads/eBooks/What_is_Social_Media_iCrossing_ebook.pdf

Mitchell, William J., Chris E. Borroni-Bird and Lawrence D. Burns, Reinventing The Automobile Personal Urban Mobility for The $21^{\text {st }}$ Century, U.S.A.: The MIT Press, 2010.

OSD, Otomotiv Sanayii 2016 Yılı Küresel Değerlendirme Raporu, 2017, erişim tarihi 15.05.2019, http:// www.osd.org.tr/sites717upload/files/2016_Degerlendirme_Raporu-2250.pdf

Pişkin, Sercan, Otomotiv Sektör Raporu: Türkiye Otomotiv Sanayii Rekabet Gücü ve Talep Dinamikleri Perspektifinde 2020 İ Pazar Beklentileri, 2017, erişim tarihi 12.05.2019, https://www.taysad.org. tr/uploads/dosyalar/06-02-2017-09-59-170206-Otomotiv_Sektor_Raporu_TSKB-2208.pdf

Schivinski, Bruno and Dariusz Dabrowski, "The Impact of Brand Communication on Brand Equity Dimensions and Brand Purchase Intention through Facebook", Gdansk University of Technology, Faculty of Management and Economics. C. 4, S. 4, 2013, s. 1-24.

Solis, Brian, Sosyal Medya İ̧̧in Temel Rehber, 2010, erişim tarihi 09.05.2019, http://www.onecaribbean. org/content/files/essentialGuidetoSocialMedia.pdf

Toksarı, M., Mürütsoy, M. ve Bayraktar, M., 2014. Tüketici Algılarını Etkileyen Faktörlerde Sosyal Medyanın Rolü: Niğde Üniversitesi İİBF Örneği. Uşak Üniversitesi Sosyal Bilimler Dergisi, 20 (20), ss. 1-28.

Tunçsiper, Çağatay, "Otomotiv sektörünün makro analizi ve strateji yönetimi”, Yüksek Lisans Tezi, Balıkesir Üniversitesi Sosyal Bilimler Enstitüsü, 2014.

Yılmaz, Erkan, “Türkiye Otomotiv Sanayinin Gelişimi ve İkinci El Otomobil Talep Fiyatının Belirleyicileri”, Yüksek Lisans Tezi, Gaziosmanpaşa Üniversitesi Sosyal Bilimler Enstitüsü, 2016.

Y1lmazdoğan, Can ve Çağıl Özel, “Sosyal Medya Pazarlamasının Otellerdeki Kullanımının Yararlarına Yönelik Yönetici Algılarının Belirlenmesi: Antalya Örneği”, Dokuz Eylül Üniversitesi İşletme Fakültesi Dergisi. C. 15, S. 1, 2014, s. 37-62. 


$$
\text { NR? }
$$

